\title{
Author correction: The effect of silver and copper nanoparticles on the growth and mycorrhizal colonisation of Scots pine (Pinus sylvestris L.) in a container nursery experiment
}

The iForest Editorial Board
Aleksandrowicz-Trzcinska M, Szaniawski A, Studnicki M, Bederska-Blaszczyk M, Olchowik J, Urban A (2018). The effect of silver and copper nanoparticles on the growth and mycorrhizal colonisation of Scots pine (Pinus sylvestris L.) in a container nursery experiment. iForest 11: 690-697. - doi: 10.3832/ifor2855011

In the original version (iForest 11: 690-697 - doi: 10.3832/ifor2855-011), one of the authors, Dr. Jacek Olchowik (ORCID: 0000-0001-5084-6758), was inadvertently omitted.

The following amendments have been done:

- the authorship of the original article has been changed as follows: Aleksandrowicz-Trzcinska M, Szaniawski A, Studnicki M, Bederska-Blaszczyk M, Olchowik J, Urban A

- the following sentence has been added to the Acknowledgements section: Jacek Olchowik gratefully acknowledges the Austrian Agency for International Mobility and Cooperation in Education, Science and Research (OeAD) for supporting his stay at the University of Vienna in 2015.

- the original article on the journal "iForest-Biogeosciences and Forestry" has been corrected accordingly on April 10, 2019; this note must be considered as part of the published article. 